Far Eastern Entomologist

\begin{tabular}{lll}
\hline Number 449: 21-28 & ISSN 1026-051X (print edition) & March 2022 \\
\hline
\end{tabular}

https://doi.org/10.25221/fee.449.4

http://zoobank.org/References/C8D0C0B7-76DD-4460-80CB-E92877410C71

\title{
NEW DATA ON CLEARWING MOTHS (LEPIDOPTERA: SESIIDAE) OF SAKHALIN ISLAND
}

\section{O. G. Gorbunov}

A.N. Severtsov Institute of Ecology and Evolution, Russian Academy of Sciences, Leninsky prospekt 33, Moscow, 119071, Russia.E-mail: gorbunov.oleg@mail.ru

Summary. Four species of clearwing moths found in Sakhalin Island in July 2021. Pennisetia hylaeiformis (Laspeyres, 1801), Sesia yezoensis (Hampson, 1919) and Synanthedon bicingulata (Staudinger, 1887) were collected using synthetic sex pheromones. Females of Synanthedon herzi Špatenka et O. Gorbunov, 1992 were collected from inflorescences of Eupatorium chinense L. (Asteraceae). Synanthedon bicingulata is recorded for the fauna of the island for the first time. Pennisetia hylaeiformis is represented by the subspecies assimilis Arita, 1992. For each of the collected species, data on the distribution, larval host plants, and sexual activity of males are given.

Key words: Sesiidae, clearwing moth, artificial sex pheromones, sexual activity, host plants, fauna, new record, Russian Far East.

О. Г. Горбунов. Новые данные о бабочках-стеклянницах (Lepidoptera: Sesiidae) острова Сахалин // Дальневосточный энтомолог. 2022. N 449. С. 21-28.

Резюме. В июле 2021 г. на Сахалине были обнаружены 4 вида бабочек-стеклянниц. Из них Pennisetia hylaeiformis (Laspeyres, 1801), Sesia yezoensis (Hampson, 1919) и Synanthedon bicingulata (Staudinger, 1887) были собраны с помощью синтетических половых феромонов. Самки Synanthedon herzi Špatenka et O. Gorbunov, 1992 были найдены на соцветиях Eupatorium chinense L. (Asteraceae). Synanthedon bicingulata впервые приводится для фауны острова. Pennisetia hylaeiformis представлена на Сахалине подвидом assimilis Arita, 1992. Для каждого из собранных видов приведены данные о распространении, кормовых растениях гусениц и половой активности самцов.

\section{INTRODUCTION}

The first information about Sakhalin Sesiidae was published by the famous Japanese entomologist S. Matsumura. He noted only two species, namely, "Sphecia contaminata Btlr." and "Bembecia hylaeiformis Lasp." (Matsumura, 1925: 118). The only female of the first mentioned species was collected at the end of July in "North-Saghalien (Rikovskoie)" [= Sakhalin, Timovsky District, Kirovskoye], and the only male of the second species was collected in "South-Saghalien (Shimizu)" [= Sakhalin, Kholmsky District, Chistovodnoye] in the latter part of August. The finding of Pennisetia hylaeiformis (Laspeyres, 1801) in 
Sakhalin does not raise any questions, but the indication of Glossosphecia contaminata (Butler, 1878) turns out to be very interesting. Firstly, this is the northernmost point of distribution of this species (Gorbunov, 2019; Gorbunov \& Arita, 2020). Secondly, the exact larval host plant of this species remains unknown. More recently, we have indicated under the question Partenocissus spp. (Vitaceae) as such (Gorbunov \& Arita, 2020). Now we can say with confidence that the only possible larval host of this species on Sakhalin is Vitis coignetiae Pulliat ex Planch. (Vitaceae) since only this species of the family is found in this part of the island (Smirnov, 2002).

In our review of the clearwing moths of the Russian Far East (Gorbunov \& Tshistjakov, 1995) we mentioned the following seven species, namely Pennisetia hylaeiformis, P. pectinata (Staudinger, 1887), Paranthrene tabaniformis (Rottemburg, 1775), Sesia yezoensis (Hampson, 1919), Synanthedon scoliaeformis (Borkhausen, 1789), S. herzi Špatenka et O. Gorbunov, 1992, S. tipuliformis (Clerck, 1759).

At the end of July 2021, I made a short-time trip to Sakhalin to test the attractiveness of artificial sex pheromones. The experiments were carried out in the valley of the Yasnomorka River upstream from the village of Yasnomorskoye, Nevelsky District (Fig. 1). In total, only three species of Sesiidae were collected for the studied sex attractants, namely P. hylaeiformis, S. yezoensis, and S. bicingulata (Staudinger, 1887). The last of these species is presented for Sakhalin for the first time. In addition, females of $S$. herzi were collected on Eupatorium chinense L. (Asteraceae) flowers.

Below I provide information on the collected species and note the activity of males and the attractiveness of artificial sex pheromones.

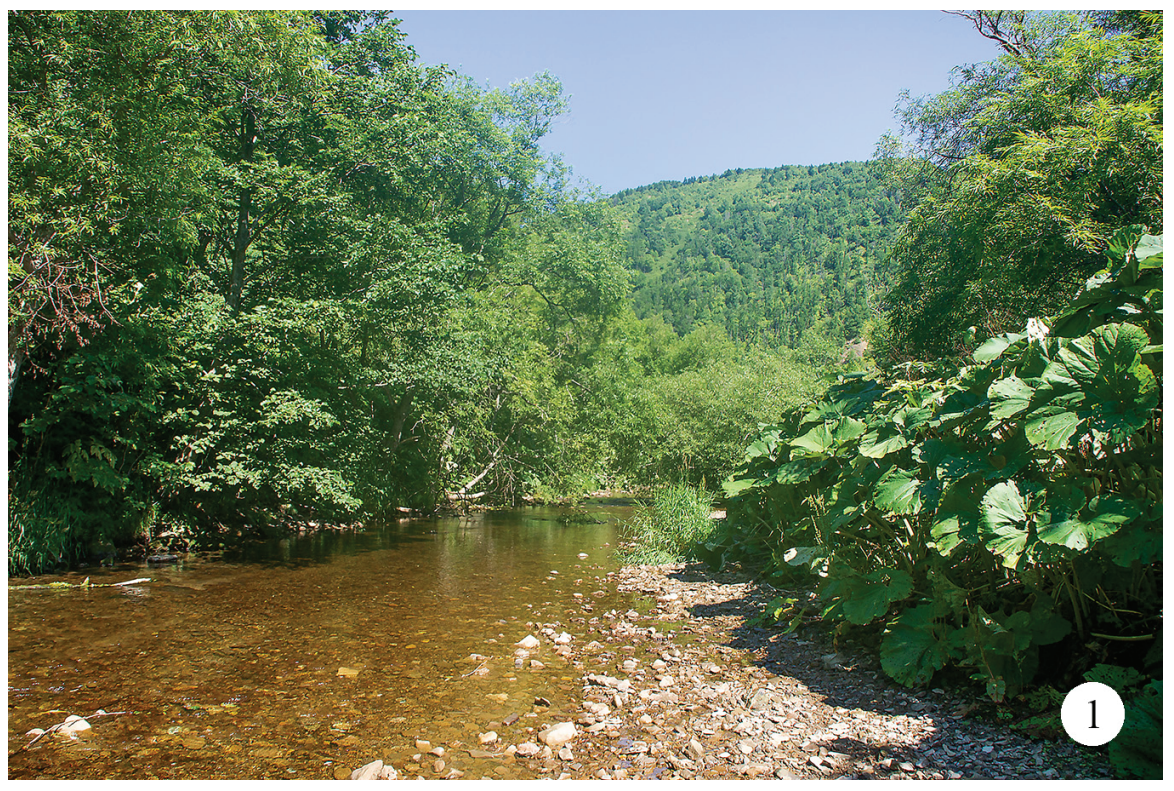

Fig. 1. Yasnomorka River upstream from the village of Yasnomorskoye, Nevelsky District, Sakhalin, 29.VII 2021. 


\section{MATERIAL AND METHODS}

Sexual activity of males was carried out using commercial artificial sex pheromones produced by PHEROBANK ${ }^{\circledR}$, Wijk bij Duurstede, the Netherlands. The following lures have been used: 1. Pennisetia hylaeiformis (Laspeyres, 1801); 2. Sesia apiformis (Clerck, 1759); 3. Eichlinia cucurbitae (Harris, 1828); 4. Vitacea polistiformis (Harris, 1854); 5. Paranthrene tabaniformis (Rottemburg, 1775); 6. Synanthedon andrenaeformis (Laspeyres, 1801); 7. Synanthedon codeti (Oberthür, 1881); 8. Synanthedon conopiformis (Esper, 1782); 9. Synanthedon culiciformis (Linnaeus, 1758); 10. Synanthedon flaviventris (Staudinger, 1883); 11. Synanthedon formicaeformis (Esper, 1783); 12. Synanthedon loranthi (Králícek 1966); 13. Synanthedon mesiaeformis (Herrich-Schäffer, 1846); 14. Synanthedon myopaeformis (Borkhausen, 1789); 15. Synanthedon polaris (Staudinger, 1877); 16. Synanthedon scoliaeformis (Borkhausen, 1789); 17. Synanthedon soffneri Špatenka, 1983; 18. Synanthedon spheciformis ([Denis et Schiffermüller], 1775); 19. Synanthedon spuleri (Fuchs, 1908); 20. Synanthedon tipuliformis (Clerck, 1759); 21. Synanthedon vespiformis (Linnaeus, 1760); 22. Paranthrenella chrysophanes (Meyrick, 1887); 23. Bembecia ichneumoniformis ([Denis et Schiffermüller], 1775); 24. Chamaesphecia empiformis (Esper, 1783).

I used all these pheromone lures in two or three places daily. The process of attracting males began at about 8 am and ended at about $5 \mathrm{pm}$.

All images were taken with a Sony ${ }^{\circledR} \alpha 450$ DSLR camera equipped with a Minolta ${ }^{\circledR} 50$ $\mathrm{f} / 2.8$ Macro lens. The processing of all illustrations is finalized with the Adobe ${ }^{\circledR}$ Photoshop ${ }^{\circledR}$ CC 2020 software.

The names of plants are given in accordance with The Plant List (2013). The material studied is kept in the collection of the A.N. Severtsov Institute of Ecology and Evolution of the Russian Academy of Sciences, Moscow, Russia (COGM).

\section{RESULTS}

\section{Pennisetia hylaeiformis (Laspeyres, 1801)}

Figs 2-5

MATERIAL EXAMINED. Sakhalin: Nevelsky District, Yasnomorka River, $46^{\circ} 44.656^{\prime} \mathrm{N}$, $141^{\circ} 58.439^{\prime} \mathrm{E}, 47 \mathrm{~m}, 24$.VII 2021, $3{ }^{\lambda}$, Gorbunov leg. (Sesiidae pictures Nos 0485-04862021); Nevelsky District, Yasnomorskoye, $46^{\circ} 44.967^{\prime} \mathrm{N}, 141^{\circ} 54.905^{\prime} \mathrm{E}, 13 \mathrm{~m}, 25$.VII 2021, 4⿳亠丷, Gorbunov leg. (Sesiidae pictures Nos 0479-0484-2021); Nevelsky District, Yasnomorka River, $46^{\circ} 44.656^{\prime} \mathrm{N}, 141^{\circ} 58.439^{\prime} \mathrm{E}, 47 \mathrm{~m}, 29$.VII 2021, $1{ }^{\AA}$, Gorbunov leg. (Sesiidae pictures Nos 0477-0478-2021).

DISTRIBUTION. Very widely in the forest zone of the Palearctic from Northern Spain and France in the west, to Kamchatka, Sakhalin and Japan in the east, from central Norway and Sweden in the north to Bulgaria, Greece and the province of Jilin in China in the south. Separate isolated populations are known from Portugal, Turkey, the North Caucasus, Georgia and Mongolia. Previously, it was known from Kirovskoye and Yuzhno-Sakhalinsk (Matsumura, 1925; Gorbunov \& Tshistjakov, 1995).

HOST PLANTS. The larvae live in the upper part of the root of Rubus idaeus L. (Rosaceae). R. idaeus subsp. melanolasius Dieck ex Focke is the only host plant on Sakhalin.

SEXUAL ACTIVITY. Males were attracted to the pheromone lure for their species from about 10 am to $2 \mathrm{pm}$.

REMARKS. In general, collected specimens are somewhat darker than specimens from the mainland part of the range. They are almost identical in coloration to the specimens from 
Hokkaido, which have been described as a separate subspecies $P$. hylaeiformis assimilis Arita, 1992 (compare Figs 2 and 4 with figs 1 and 2 in Arita, 1992: 452). Therefore, the Sakhalin population of this species should be attributed to the subspecies assimilis Arita, 1992.
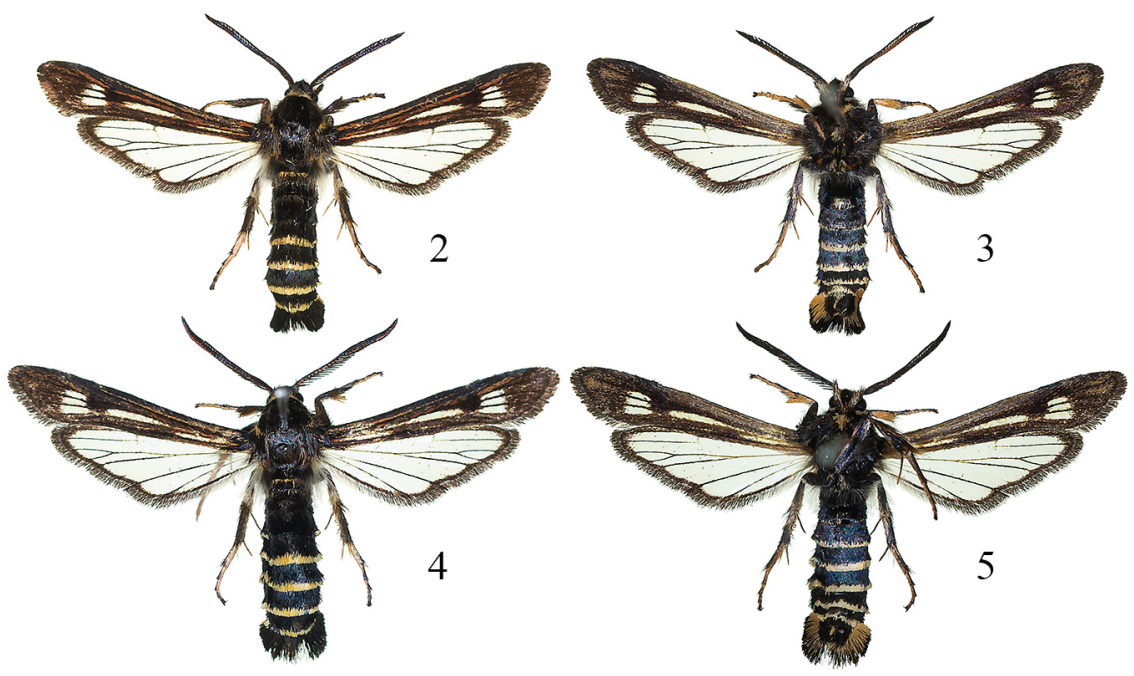

Figs 2-5. Males of Pennisetia hylaeiformis (Laspeyres, 1801). 2-3 - Sesiidae picture Nos 0479-0480-2021. Alar expanse 25.6 mm; 4-5 - Sesiidae picture Nos 0483-0484-2021. Alar expanse $27.2 \mathrm{~mm} ; 2,4$ - dorsal view; 3, 5- ventral view.

\section{Sesia yezoensis (Hampson, 1919)}

Figs 6-11

MATERIAL EXAMINED. Sakhalin: Nevelsky District, Yasnomorka River, 46 44.443'N, $141^{\circ} 56.752^{\prime} \mathrm{E}, 16 \mathrm{~m}, 24$.VII 2021, 4${ }^{\wedge}$, Gorbunov leg. (Sesiidae pictures Nos 0495-04962021); same locality, 25.VII 2021, 40., Gorbunov leg.; Nevelsky District, Yasnomorskoye, $46^{\circ} 44.967^{\prime} \mathrm{N}, 141^{\circ} 54.905^{\prime} \mathrm{E}, 13 \mathrm{~m}, 26$.VII 2021, 8`^, Gorbunov leg. (Sesiidae pictures Nos 0487-0488-2021); Nevelsky District, Yasnomorka River, 46 $44.611^{\prime} \mathrm{N}, 141^{\circ} 55.810^{\prime} \mathrm{E}, 24 \mathrm{~m}$, 26.VII 2021, 4^, Gorbunov leg. (Sesiidae pictures Nos 0489-0490-2021, 0493-0494-2021); same locality, 27.VII 2021, 9તे, Gorbunov leg. (Sesiidae pictures Nos 0491-0492-2021); Nevelsky District, Yasnomorka River, $46^{\circ} 44.778^{\prime} \mathrm{N}, 141^{\circ} 56.104^{\prime} \mathrm{E}, 54 \mathrm{~m}, 28$.VII 2021, 50, Gorbunov leg. (Sesiidae pictures Nos 0497-0502-2021); Nevelsky District, Yasnomorka River, $46^{\circ} 44.611^{\prime} \mathrm{N}, 141^{\circ} 55.810^{\prime} \mathrm{E}, 24 \mathrm{~m}, 29$.VII 2021, 50', Gorbunov leg. (Sesiidae pictures Nos 0503-0508-2021); Yuzhno-Sakhalinsk, Airport, 46 53.207'N, 142 43.630'E, 22 m, 30.VII 2021, 1 exuvium, Gorbunov leg.

DISTRIBUTION. In the Eastern Palearctic, from the Trans-Baikal Territory in the west to the South Kuriles in the east, and from the Khabarovsk Territory and South Sakhalin in the north to South Korea and Honshu in the south. Previously, it was known only from Yuzhno-Sakhalinsk and Novoaleksandrovsk (Gorbunov \& Tshistjakov, 1995).

HOST PLANTS. The larvae live in the lower parts of the trunks and in the upper parts of the large roots of Salix udensis Trautv. et C.A. Mey. and some other tree willows, and, sometimes, Pupulus spp. (Salicaceae). S. udensis is the only host plant on the Yasnomorka River valley. 

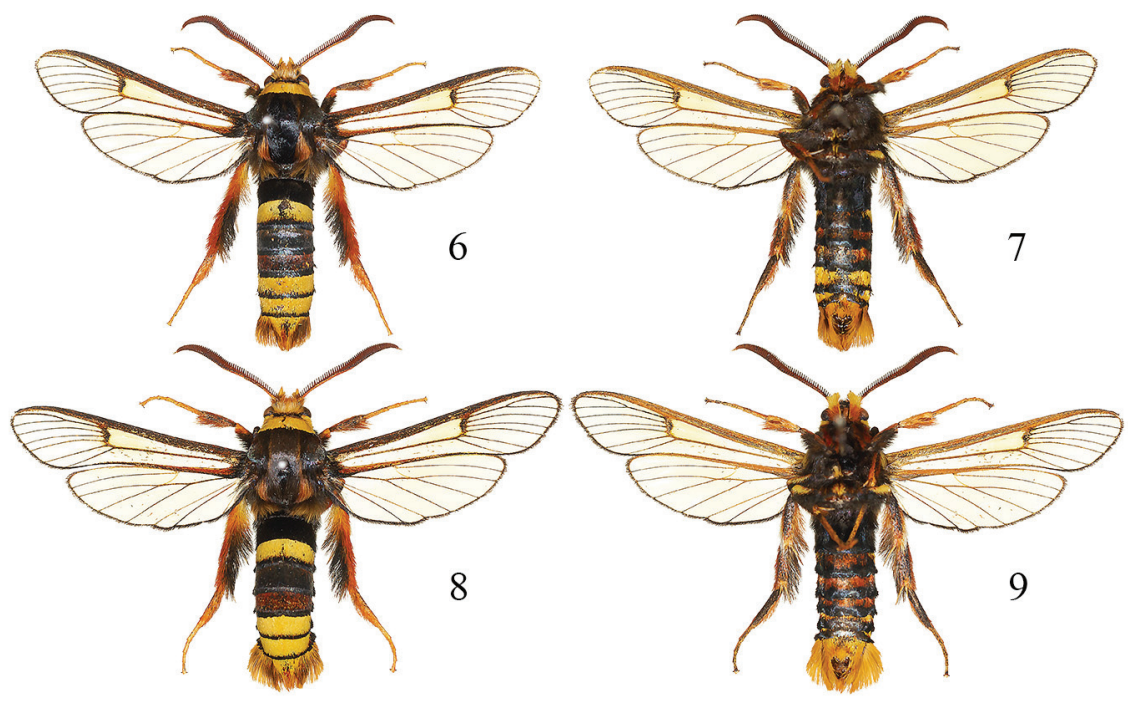

Figs 6-9. Males of Sesia yezoensis (Hampson, 1919). 6, 7 - Sesiidae picture Nos $0497-$ 0498-2021. Alar expanse $41.0 \mathrm{~mm} ; 8,9$ - Sesiidae picture Nos 0505-0506-2021. Alar expanse $45.6 \mathrm{~mm} ; 6,8$ - dorsal view; 7, 9 - ventral view.
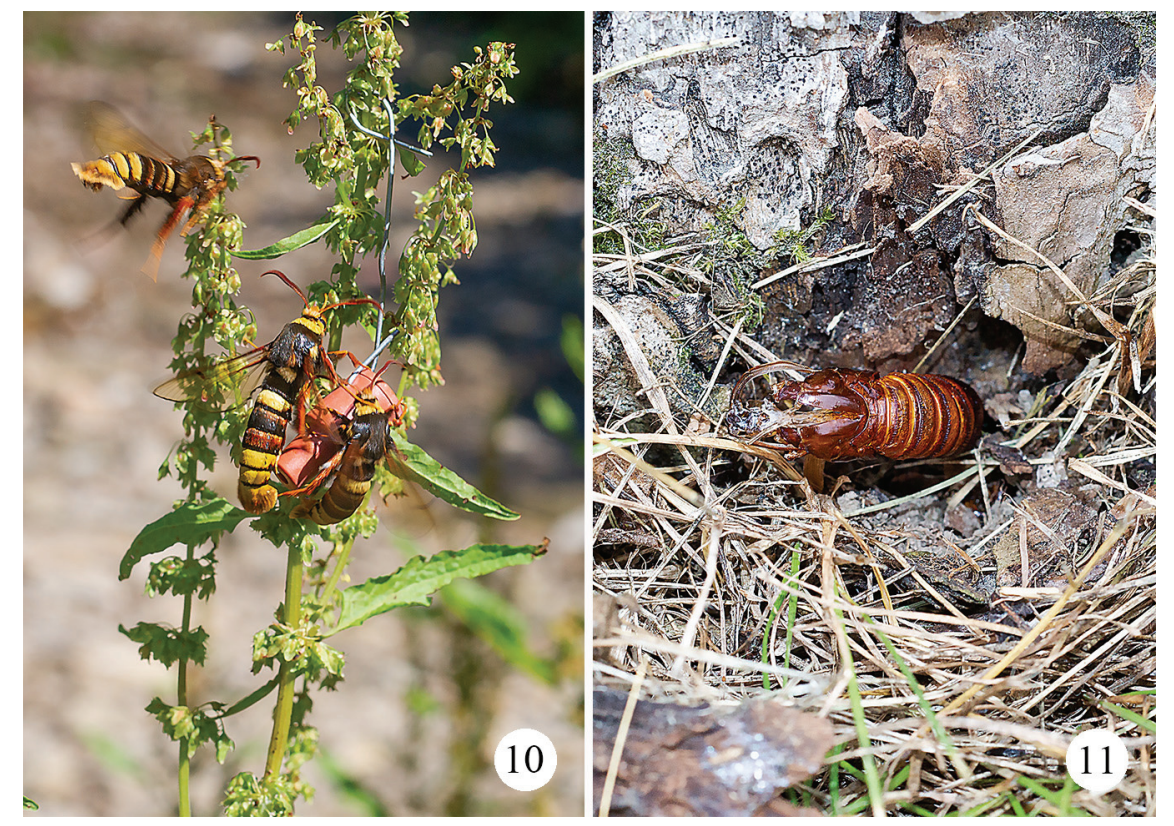

Figs 10-11. Sesia yezoensis (Hampson, 1919). 10 - males attacking a pheromone lure 29.VII 2021; 11 - an exuvium at the base of the trunk of Populus sp. near Yuzhno-Sakhalinsk International Airport. 30.VII 2021. 
I also found an exuvium of Sesia yezoensis at the base of the trunk of Populus sp. near Yuzhno-Sakhalinsk International Airport (Fig. 11).

SEXUAL ACTIVITY. Males responded very actively to the pheromone lure for Sesia apiformis from about 9 am to $4 \mathrm{pm}$ (Fig. 10). This is the time when the valley of the Yasnomorka River was well lit by the sun. In total, about a hundred males were attracted, of which only 39 were caught.

\section{Synanthedon bicingulata (Staudinger, 1887)}

Figs 12-13

MATERIAL EXAMINED. Sakhalin: Nevelsky District, Yasnomorka River, 46 $44.611^{\prime} \mathrm{N}$, $141^{\circ} 55.810^{\prime} \mathrm{E}, 24 \mathrm{~m}, 26 . \mathrm{VII}$ 2021, 10`, Gorbunov leg. (Sesiidae pictures Nos 0475-04762021).

DISTRIBUTION. In the Eastern Palearctic, from the Amur region in the west to Sakhalin in the east, and from the south of the Khabarovsk Territory in the north to South Korea and Beijing in the south. This is the first record of this species for the fauna of Sakhalin.

HOST PLANTS. The larvae live in the butt part of the trunks of Prunus maackii Rupr. and cultivated Malus spp. in Primorye (Tschistjakov, 2012), and Prunus sp. (Rosaceae) in Korea (Arita et al., 2004). The host plant on Sakhalin is unknown.

SEXUAL ACTIVITY. A single male was attracted to the Paranthrene tabaniformis pheromone lure at about $2 \mathrm{pm}$.

\section{Synanthedon herzi Špatenka et O. Gorbunov, 1992}

Figs 14-17

MATERIAL EXAMINED. Sakhalin: Nevelsky District, Yasnomorka River, 46 44.612'N, $141^{\circ} 56.281^{\prime} \mathrm{E}, 23$ m, 24.VII 2021, 1 \% , Gorbunov leg.; Nevelsky District, Yasnomorka River, $46^{\circ} 44.680^{\prime} \mathrm{N}, 141^{\circ} 56.082^{\prime} \mathrm{E}, 31 \mathrm{~m}, 27 . \mathrm{VII}$ 2021, 1 웅, Gorbunov leg. (Sesiidae pictures Nos 0473-0474-2021); Nevelsky District, Yasnomorka River, 46 $44.680^{\prime} \mathrm{N}, 141^{\circ} 56.082^{\prime} \mathrm{E}, 22 \mathrm{~m}$, 28.VII 2021, 1 q Gorbunov leg. (Sesiidae pictures Nos 0471-0472-2021).

DISTRIBUTION. In the Eastern Palearctic, from the Irkutsk region and Mongolia in the west to Kamchatka in the east, and from the Magadan region in the north to Primorye and Hokkaido in the south. Previously, it was known in Sakhalin from Dudino and Novoaleksandrovsk only (Špatenka \& Gorbunov, 1992; Gorbunov \& Tshistjakov, 1995).

HOST PLANTS. The larvae live in places of damage to the bark of trunks or branches of various Salix spp. (Salicaceae). Salix udensis Trautv. et C.A. Mey. should be considered the most likely host plant on Sakhalin.

SEXUAL ACTIVITY. Although the females were active and were collected on Eupatorium chinense L. (Asteraceae) flowers, none of the males were attracted to any of the pheromone lures used.

REMARKS. Here it is appropriate to point out the fact that the pheromone lure for Synantedon formicaeformis available in this pool was successfully used to collect $S$. formicaeformis in the Republic of Crimea and Moscow region. Perhaps this should be considered one of the arguments in favor of the opinion on the species status of $S$. herzi. I have always considered and still consider $S$. herzi to be a good species, and not a subspecies or even a junior synonym of $S$. formicaeformis. 


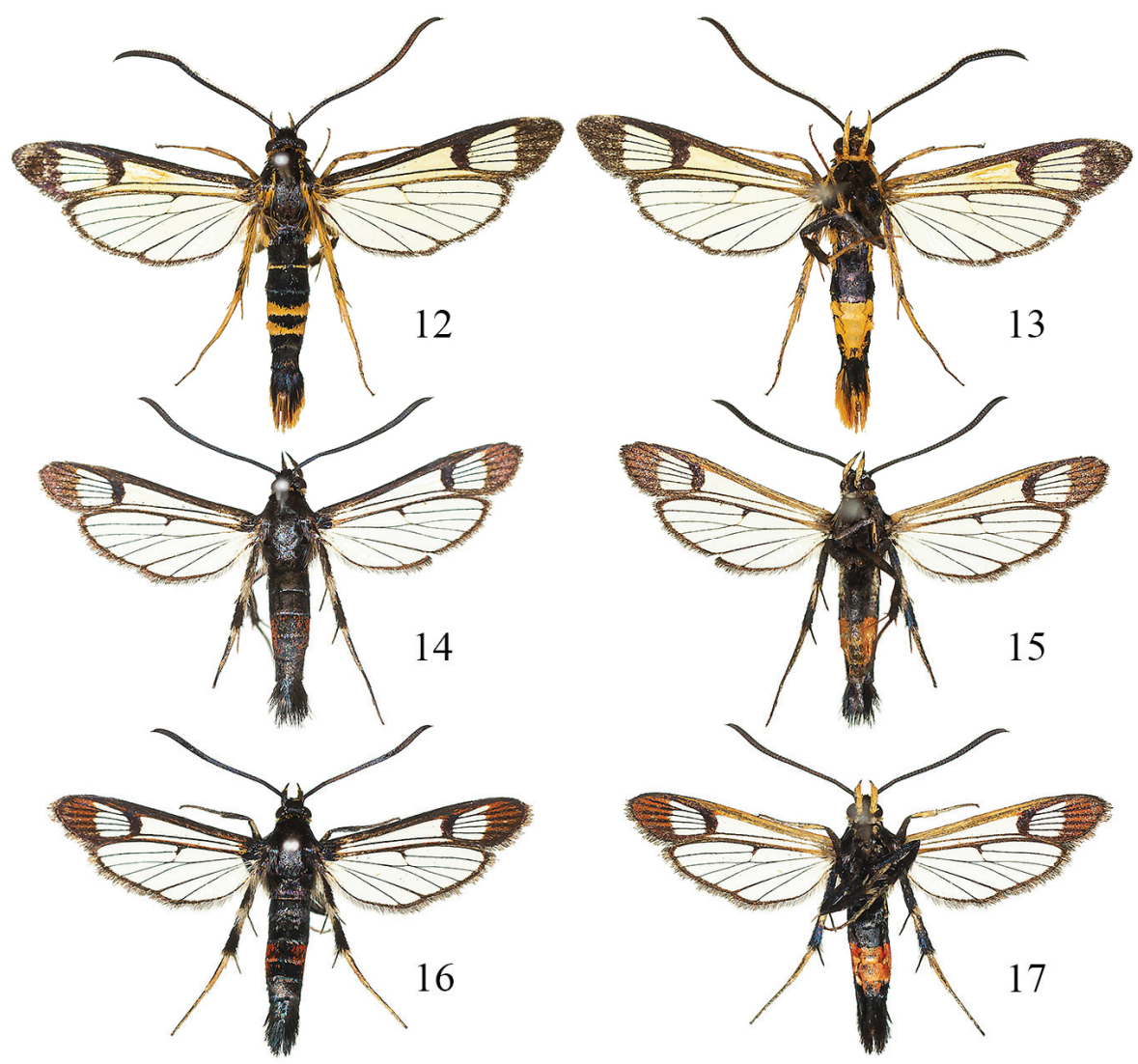

Figs 12-17. Synanthedon spp. 12, 13 - S. bicingulata (Staudinger, 1887), male. Sesiidae picture Nos 0475-0476-2021. Alar expanse $26.0 \mathrm{~mm}$; 14-17 - S. herzi Špatenka et O. Gorbunov, 1992, females. 14, 15 - Sesiidae picture Nos 0471-0472-2021. Alar expanse 22.9 $\mathrm{mm} ; 16,17$ - Sesiidae picture Nos 0473-0474-2021. Alar expanse $22.8 \mathrm{~mm} ; 12,14,16-$ dorsal view; $13,15,17$ - ventral view.

\section{ACKNOWLEDGEMENTS}

I would like to express my heartfelt gratitude to my friend Andrey Zagorinsky (Moscow, Russia) for all-round assistance during this and other expeditions. I also thank Olga Titova (Kholmsk, Russia) for the valuable information about Sakhalin Sesiidae and to the staff of the Yasnomorskaya campsite for accommodation and a warm welcome.

The study was conducted using the equipment of the Joint Usage Center "Instrumental methods in ecology" at the A.N. Severtsov Institute of Ecology and Evolution, Russian Academy of Sciences (Moscow, Russia). The investigation was fulfilled within the State project No AAAA-A18-118042490060-1 of the A.N. Severtsov Institute of Ecology and Evolution, Russian Academy of Sciences. 


\section{REFERENCES}

Arita, Y. 1992. The genus Pennisetia Dehne (Lepidoptera, Sesiidae) of Japan. Japanese Journal of Entomology, 60(2): 449-462.

Arita, Y., Bae, Y.S., Lee, C.M. \& Ikeda, M. 2004. Sesiidae (Lepidoptera) of Korea. Transactions of the Lepidopterous Society of Japan, 55(1): 1-12.

Gorbunov, O.G. 2019. Sesiidae. P. 158-161. In: Sinev, S.Y. (Ed.). Catalogue of the Lepidoptera of Russia. Edition 2. St. Petersburg: Zoological Institute RAS. [version 2.1 of 10.06.2021; https://www.zin.ru/publications/books/Lepidoptera_Russia/]

Gorbunov, O.G. \& Arita, Y. 2020. A new species of the genus Toleria Walker, 1865 ["1864”] from Vietnam, with a catalogue of Asian Cissuvorini (Lepidoptera: Sesiidae). Zootaxa, 48(2): 349-360. DOI: 10.11646/zootaxa.4802.2.8

Gorbunov, O.G. \& Tshistjakov, Y.A. 1995. A review of the clearwing moths (Lepidoptera, Sesiidae) of the Russian Far East. Far Eastern Entomologist, 10: 1-18.

Matsumura, S. 1925. An enumeration of the butterflies and moths from Saghalien, with descriptions of new species and subspecies. Journal of the College of Agriculture, Hokkaido Imperial University, 15(3): 83-196.

Smirnov, A.A. 2002. Distribution of vascular plants in Sakhalin Island. Institute of Marine Geology and Geophysics, Yuzhno-Sakhalinsk. 245 pp. [In Russian]

Špatenka, K. \& Gorbunov, O.G. 1992. Vier neue paläarktische Glasflügler (Sesiidae, Lepidoptera). Entomofauna, 13(23): 377-393.

The Plant List. 2013. Version 1.1. Published on the Internet; http://www.theplantlist.org/ (accessed 10 January 2022).

Tschistjakov, Y.A. 2012. A new data on biology of Synanthedon bicingulatum (Staudinger, 1887) (Lepidoptera, Sesiidae). Amurian zoological journal, 4(2): 157-159.

(C) Far Eastern entomologist (Far East. entomol.) Journal published since October 1994. Editor-in-Chief: S.Yu. Storozhenko

Editorial Board: A.S. Lelej, S.A. Belokobylskij, M.G. Ponomarenko, V.A. Mutin, E.A. Beljaev, E.A. Makarchenko, A.V. Gorochov, T.M. Tiunova, M.Yu. Proshchalykin, S.A. Shabalin, V.M. Loktionov

Address: Federal Scientific Center of the East Asia Terrestrial Biodiversity (former Institute of Biology and Soil Science), Far East Branch of the Russian Academy of Sciences, 690022, Vladivostok-22, Russia.

E-mail: storozhenko@biosoil.ruweb-site: http://www.biosoil.ru/fee 